\title{
TECHNOLOGY VERSUS INDIVIDUAL: AN ANALYSIS ON INTERACTIVE FILM BLACK MIRROR: BANDERSNATCH
}

\author{
Onur O. AKŞiT \\ Ege University, Turkey \\ onuraksit@gmail.com \\ https://orcid.org/0000-0002-1648-122X \\ Azra K. NAZLI \\ Ege University, Turkey \\ azraknazli@gmail.com \\ https://orcid.org/0000-0003-0565-1278
}

\begin{abstract}
One of the basic themes of technology-based dystopian narratives appears as the problem of selfdetermination. In these narratives that proceed through concepts such as surveillance and control; there are descriptions of a dark future in which the individual becomes an object. Netflix production Black Mirror: Bandersnatch (David Slade, 2018) examines the loss of individuality and the loss of selfdetermination. The film, as a technology-based narrative, connects these concepts to the impact of technology. In the narrative, a critical discourse has been developed over the possible impacts of technology, by removing the self-determination of the protagonist by giving the audience the ability to choose instead. This study aims to examine the effects of technology on individuals, and their freedom through the science fiction anthology: Black Mirror. In this study, the issue of self-determination of an individual through the concepts of surveillance and technology is discussed within the interactive film Bandersnatch, a part of the anthology. A discourse analysis is applied to the film through three basic interpretative repertoires: (a) "Loss of individuality", (b) "loss of reality", (c) "decentralization". It is concluded that; the messages include increase of surveillance and control caused by technology in postmodern society, will have effects on the individual, especially the loss of individuality is depicted by Bandersnatch as in other Black Mirror episodes. Another result is that, the Black Mirror anthology gives a critique of the present while narrating the future.
\end{abstract}

Keywords: Technology, Surveillance, Individual, Interactive Film, Communication Studies

\section{TEKNOLOJİ KARŞISINDA BİREY: ETKİLEŞIMLİ FILM BLACK MIRROR: BANDERSNATCH ÜZERINE BİR ÇÖZÜMLEME}

\section{ÖZ}

Teknoloji merkezli distopyan anlatıların temel temalarından bir tanesi bireylik yitimi sorunu olarak karşımıza çıkar. Gözetim ve kontrol gibi kavramlar üzerinden ilerleyen bu anlatılarda bireyin nesneleştiği karanlık bir gelecek tasviri görülür. Black Mirror: Bandersnatch (David Slade, 2018) isimli Netflix yapımında da bireylik yitimi ve özgür iradenin yok oluşu teknolojinin etkisine bağlanarak teknoloji merkezli bir metin kurgulanmıştır. Anlatıda, başkarakterin özgür iradesinin elinden alınıp seçimlerinin izleyiciye verilmesi ile teknolojinin olası etkileri üzerinden eleştirel bir söylem geliştirilmiştir. Bu çalışmanın amacı, teknolojinin bireye ve özgürlüğüne olan etkilerini bir bilim kurgu antolojisi olan Black Mirror yapımı üzerinden ele almaktır. Çalışmada gözetim ve teknoloji konuları üzerinden bireyin özgür irade sorunu, antolojinin bir bölümü olan Bandersnatch isimli interaktif film ile ele alınmıştır. Üç temel yorumlayıcı repertuar aracılığıyla filme söylem analizi uygulanmıştır: (a) "Bireylik yitimi", (b) "gerçeklik yitimi", (c) "merkezsizleştirme". Çalışma ile, postmodern toplumda 
teknolojinin, gözetim ve denetimi attıracağ 1 ve bu yolla bireylik yitimi başta olmak üzere birey üzerinde etkili olacağına yönelik mesajların diğer Black Mirror yapımlarında olduğu gibi Bandersnatch filminde de tasvir edildiği ve Black Mirror'ın geleceği resmederken bugünün eleştirisini veren bir yapım olduğu sonuçlarına ulaşılmıştır.

Anahtar Kelimeler: Teknoloji, Gözetim, Birey, İnteraktif Film, İletişim Çalışmaları

\section{INTRODUCTION}

"I knew who I was this morning, but I've changed a few times since then." Lewis Carroll, Alice's Adventures in Wonderland \& Through the Looking-Glass

Thinking about self-determination is, one of the core values that make us a human being. The individual lives in the community have to compromise their freedom in the grip of management, order and control. The development of technological tools and systems has also created new control areas and in a way that one must exchange their individuality and freedom with tools and systems that make life easier. In this context, the negative effects of technology on the individual constitute the basis of technologybased critical readings. On the axis of all those topics, possible future scenarios also envisage situations in which the effects of technology will be turned to a darker and more controlling level.

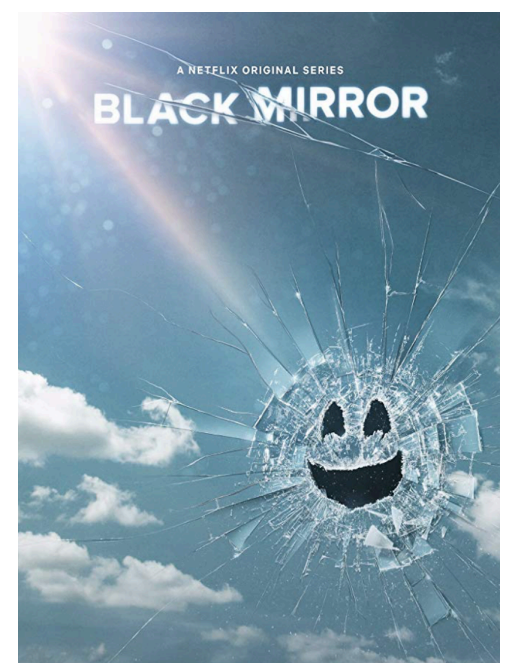

Picture 1. Official poster of the series. Obtained from imdb.com. Accessed on 31.01.20.

Black Mirror: Bandersnatch is a dystopian science fiction film, stands out with being interactive with the audience, which was released in 2018 via Netflix's digital platform worldwide. The film has been presented to the audience as part of the uncomplimentary science fiction series Black Mirror anthology, which has released 22 episodes since 2011. Each episode can be considered as a medium-length television film with their over one hour runtime. The name comes from the digital screen of devices. When the screen turns off, it becomes a mirror that users see themselves suddenly. For nearly a decade, Black Mirror becomes a popular culture term about the negative side effects of digital technologies on individuls and society especially among young people. The $2018 \mathrm{film}$, written by anthology's creator and head writer Charlie Brooker and directed by David Slade, is one of the limited examples of the interactive film genre that has a history up to 25 years. This level of interactivity becomes possible by the digital platform Netflix's technological advance. So the audience can control behaviours and choices of the main character and see what happens by the remote control, easily.

In this study, Bandersnatch will be evaluated through discourse analysis though three basic interpretative repertoires: (a) "Loss of individuality", (b) "loss of reality", (c) "decentralization" with companion concepts such as paranoia, cyberspace and digital simulation, which considered as realities and concerns about the postmodern world. As cyberspace is an element defining the postmodern subject of today, it will be emphasized that, the narrative of the film provides a space for the individual under the dominance of technological surveillance, and digitalized culture. In the context of the interactive

Research Article - This article was checked by iThenticate 
content of the film, the relationship between the user and technology, and therefore the intertwining of physical space and virtual space, will be explored in the context of self-concerns. In the theoretical framework of the the analysis, literature on postmodernity, and related cyberspace and new communication technologies will be utilized.

\section{BACKGROUND}

\section{Individual Within The Community}

Human is an entity, that constructs itself within the community. Maintaining a completely private life for the human, can be expressed in the sense of being deprived of the essentials for truly human life. From the reality of being seen and heard by others; it means depriving of the "objective" relationship of unification and separation through a world of something common with others, the possibility of achieving something more lasting than life itself. The deprivation of "objective" relations with others, and the reality provided by them, is transformed into the phenomenon of mass loneliness which, in modern conditions, takes on the most extreme and most inhuman form. The reason for this rapprochement is that, the mass society has destroyed not only the public area but also the private area; not only people from their places in this world, but also in which they feel themselves protected against this world, and even those who are excluded from this world are deprived of their private homes, where they can find a substitute for the warmth of the home in the narrow reality of family life (Arendt, 1994, pp. 86-87).

Massification can be expressed as two extremes opposite to individualization. As the rise of individualization will reduce sociality, mass society will also bring about the dissolution of individuality. The orientation of individuals from the most microstructure to the macro community in which the singular orientation of individuals has to be filed. In the Black Mirror series, the subject as the individual who is opposed to the mass, is frequently mentioned. For example, in the third season of the series, episode named Nosedive (Joe Wright, 2016) is based on the control of the mass structure upon the individual. Lacie Pound's character, which depicts the social stratification formed by individuals scoring each other on social media, avoids behaving in the way she feels by seeking a higher status in the social structure. According to Hood, the mind that produces our self-perception is the product of a brain, that has evolved to socialize. But the social brain changes radically, because of the existence of others and the need to be compatible with them. This is a must. Joining a group can be one of the most positive experiences, but it is also one of the most worrying challenges $(2014$, p. 215).

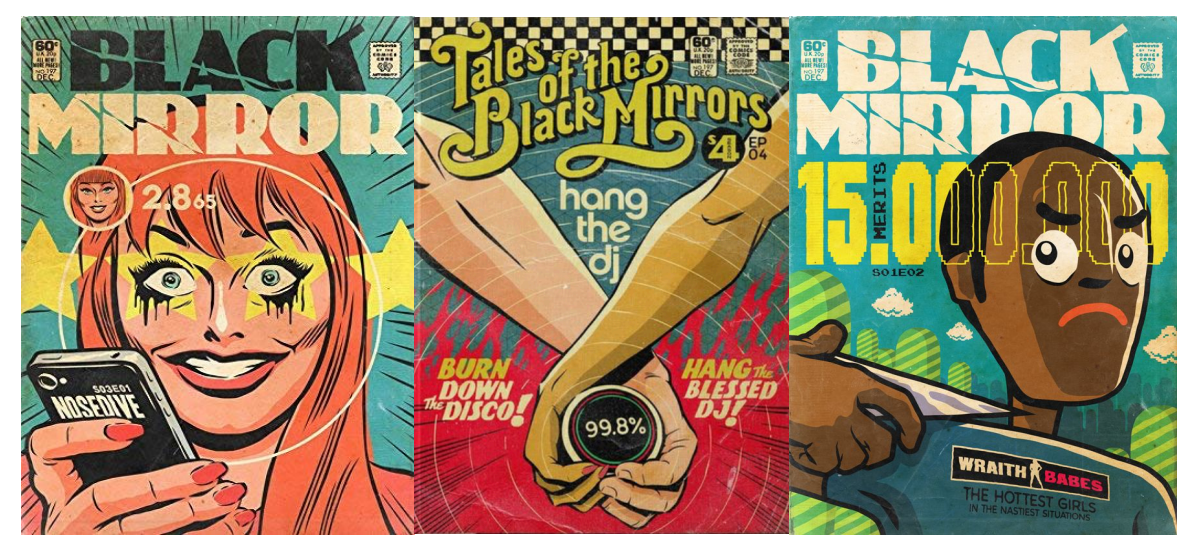

Picture 2,3 \& 4. Alternative poster designs for the episodes of Black Mirror by Brazilian pop culture illustrator \& visual artist Butcher Billy show the effect of series on popular youth culture. Obtained from imdb.com. Accessed on 31.01.20.

In the 1980 s, with the acceleration of social solidarity and disintegration in the community spirit, all collective institutions were weakened, and the sense of trust was damaged as the relations that held people together eroded (Furedi, 2001, p. 186). The identity revolution is expressed as a new formation

Research Article - This article was checked by iThenticate 
characterized by the subjectivity, that comes to the fore in the process of constructing the meaning of life personally. For this, you need to see identity as a project, something that is built in the future. However, in the age of identity, as is often observed, most people look for the meaning of life in the past, and see identity as something to be found, not something to be built (Bilgin, 2007, p. 51). In episode Hang The DJ (Tim van Patten, 2017), it is about making an individual's choices about their life by leaving this under the control of technology. In the episode that depicts a world where the individual trusts technology more than their perception and choices, a scenario is drawn in which the individual enters a process outside their decisions and because of that the individual distances from both themselves and the community.

Any attempt to answer the question "Who are we?" leads the individual to examine the identity problem. Identity is often used to refer to three different phenomena: The continuity of a subject, that is not affected by environmental changes below a certain threshold; the concept of unity that creates the boundaries of the subject, and allows us to separate it from the others; and finally, the relationship between the two elements that enable us to accept them as identical (Melucci, 2013, p. 40). The key point of the individualization process could be considered as the autonomy construction of the social actors, that became subjects in the process. Social actors do this by defining their original projects in interaction with the institutions of society, but without submitting to them. This is the case for a small group of individuals, but these individuals initiate a new culture in all areas of social life thanks to their leadership and mobilization (Castells, 2016, p. 11). In the Black Mirror series, the issue of autonomy of the individual is discussed in the episode called Fifteen Million Merits (Euros Lyn, 2011). In this episode, the character named Bing wants to get out of the life imposed by the system, but he cannot stand out from the impositions of the environmental changes, that Melucci mentioned above and is dragged from being the subject to the object bounded by the media.

\section{Information-Communication Technologies and Surveillance Society}

As Benjamin Franklin points out, man is "a tool-making animal". Tools are worldly objects, and civilizations can be classified by treating the tools as the criteria. In modern society, the relationship between purpose and tool is ambiguous. Instead of using the machines as the means of the service of human needs and desires, a structure emerges where people become the servants of the machines and "adapts themselves to machines' needs". In such an environment, where production is essentially a preparation for consumption, the distinction between purpose and means is lost (Arendt, 1994, pp. 198199). There are some approaches to the negative effects of information-communication technologies on the individual. These can be listed as concerns about the privacy rights of individuals (surveillance), technology addiction (Konsbruck, 2009, p. 6), and information pollution through informationcommunication technologies.

The control of individual's production is a predicament that manifests itself from the transition to a sedentary life. The dilemma of human, who creates their control with their own hands, is a subject covered in many films and books. When we look at technology and information-communication technologies, in particular, the concept of surveillance comes into play. The origin of surveillance is shown in the Oxford English Dictionary (2019) as the Latin word "vigilare" (to watch). The combination of French words "sur" (over) and "veiller" (watch) is used today to express the modern society. Surveillance may be social, technological, bureaucratic, military or economic.

Harold Adams Innis and Marshall McLuhan treat the history of communication technology, as the center of the history of civilization. According to them, it is the communication technology, that makes and changes the history of civilization. Innis and McLuhan stated that; there were military, industrial and administrative technologies, but their impact on society was not equal to the impact of communication technology. Communication Technologies, are central to all technologies (as cited in Erdoğan \& Alemdar, 1990, p. 153). The dystopian narrative structure, that tells communication technology puts the individual under surveillance has been the subject of some episodes of the Black Mirror series. Be Right Back (Owen Harris, 2013) and Arkangel (Jodie Foster, 2017) are one of the two examples of them. In Be Right Back, there is a technology that produces artificial intelligence based on the past social media

Submit Date: 06.07.2020, Acceptance Date: 10.08.2020, DOI NO: 10.7456/11004100/013

Research Article - This article was checked by iThenticate

Copyright (C) The Turkish Online Journal of Design, Art and Communication 
datas of the deceased relatives. As the reason for the alienation experienced by the main character Martha, who wants to benefit from this technology, the control established by the information and communication technologies on the lives of the people is depicted.

Another episode, Arkangel is on the use of a new technology, that allows a concerned mother to follow her daughter, Sara. The dark side of the technology is handled on the surveillance axis, with the device that allows the mother to keep every moment of Sara under surveillance, and the mother's attitude that takes away her daughter's freedom. In this context, it is seen that the glorification of security accompanied by risk warnings creates an intellectual and ideological atmosphere, that is hostile to human beings. Society and individuals are called to restrain their determination, and to limit their behavior. Today, the fear of risk-taking creates a society that applauds the victim, not the hero. It is stated that, not being active but being passive, not the courage but the security are important virtues. According to this; to comfort the helpless individual, the impression is created that survival in this world full of crises and disasters is a great job (Furedi, 2001, pp: 38-39).
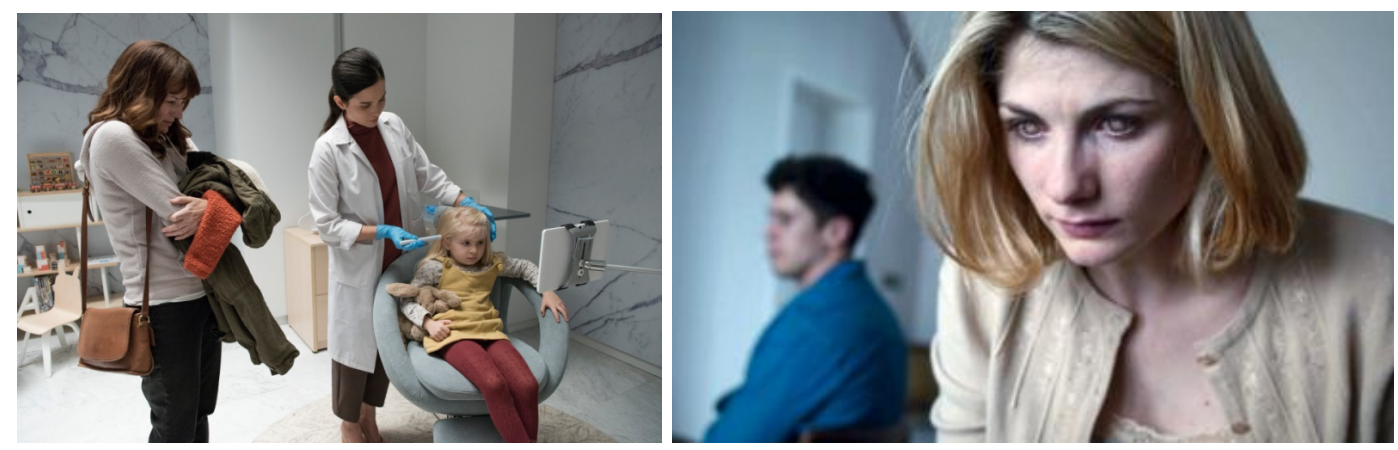

Picture 5 \& 6. Stills from the mentioned technologies from the episodes of Black Mirror antology. On the left: Arkangel (2017), on the right: The Entire History of You (2011). Obtained from netflix.com. Accessed on 31.01.20.

Each human-built, sufficiently developed structure tends to turn and take the user into itself. Technology forces any of the human senses to come forward; at the same time, other senses are either weakened or temporarily eliminated. This process once again activates the tendency of human beings to worship their own extensions as a form of divine quality. When advanced enough, mankind becomes "a creature of his own machine" (McLuhan \& Innis, 2001, p. 25). The episode named The Entire History of You (Brian Welsh, 2011) deals with technology, that can access a memory implant that records, sees and hears everything that individuals do. The episode about the possible effects of a digital video recorder built into the brain, emphasizes the dangerous aspect of surveillance. The implications of a technology that jeopardizes the privacy of individual life have been demonstrated from human relations to the social structure, and the effects of surveillance have been laid out.

\section{Cyberspace via Post-geographical and Post-historical Context}

Humanities have discovered the world through geographical discoveries throughout history, discovered the transformation of organic life with paleontological studies, and space with astronomy. All this has been accomplished utilizing technological tools. The more people have discovered the environment, the more level of cognition about themselves established. This phenomenon occurred within a certain continuity with cumulative progress. Like all life, the human is an entity that exists in a certain period and has a certain volume in space. In this context, human beings, like all living things, cannot be evaluated independently of space and time. Assumptions on time and space have been transformed historically, in addition to scientific studies, philosophical approaches have been effective in this transformation. The view that space exists within time, the idea that space is defined via time is groundbreaking in both scientific and philosophical terms and finds definition with the concept of spacetime. 
The modern history of views on space and time has been heavily influenced by developments in science since the 16th \& 17th centuries with the position of Newton's physics which plays an important role. While Newton emphasized the concept of an absolute and linear space-time, time is the changes in the physical universe, according to theorists of relativity. Since Hermann Minkowski's comment on Einstein's theory of relativity; time and space are no longer expressed by physicists as independent entities (de Mul, 2008, p. 24). Since time is a dimension we experience and are in, our perception of time has also been culturally transformed throughout the centuries. It can be said that technology has a direct effect on this transformative process. For example, the perception of distance between places transformed through technologies in the field of transportation. According to Pickstone, the technology requires an intertwining of science-related ways of knowing and technology-related ways of making and producing. Technology then can be defined as a "timeless" concept (2005, p. 154).

Although space and time have been taken from an objective point of view in scientific thought, it can also be seen philosophically, that time and space can be defined through our experience. Philosophically, the experience of time and therefore of space can be discussed through Kant and Heidegger. While Kant explains the time with subjectivity, Heidegger, who bases his philosophical view on the concept of time, "dasein", does not only consider the past as an ended process, according to him, we continue to experience it. Deleuze and Guattari, on the other hand, emphasized the unity of chaos and cosmos with the concept of "chaosmos" and co-existence instead of human existence or dasein. (Batukan, 2017, p. 31).

The detachment of time, space, and existence from the limitations opens the gateways for the thought of post-history and geography. The strong depiction of this idea in literature is dominantly seen in the early example H.G. Well's Time Machine in 1895:
"We are always getting away from the present moment. Our mental existences, which are immaterial and have no dimensions, are passing along the Time-Dimension with a uniform velocity from the cradle to the grave... You are wrong to say that we cannot move about in Time. For instance, if I am recalling an incident very vividly I go back to the instant of its occurrence: I become absent-minded, as you say. I jump back for a moment. Of course we have no means of staying back for any length of Time, any more than a savage or an animal has of staying six feet above the ground. But a civilized man is better off than the savage in this respect. He can go up against gravitation in a balloon, and why should he not hope that ultimately he may be able to stop or accelerate his drift along the Time-Dimension, or even turn about and travel the other way?" (Wells, 2019, p. 31).

Post-geography and post-history define the transition to cyberspace with advanced technologies and expresses the individual's existence independently from time and space. Along with the transition to verbal, written, and digital culture, the narrative structure is transformed with technological tools, as well as exemplary works that predict reality. Science-fiction sheds light on our future cyber-existence in terms of presenting the possible worlds with technological tools by shedding light on the future with the unity of the current and possible. The emergence of techno-nature as space and thus time in sciencefiction create examples of post-geographic and post-historical elements.
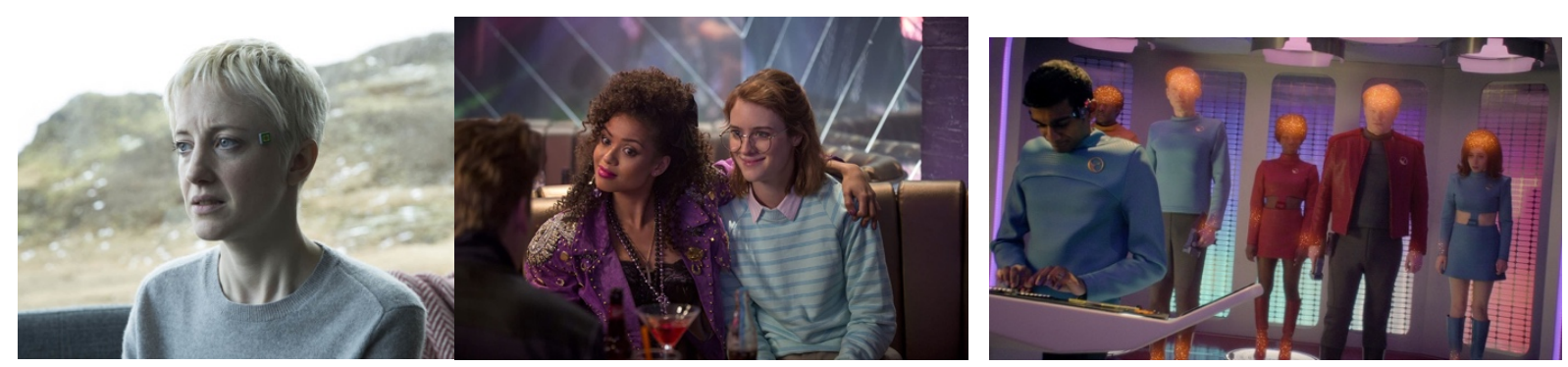

Picture 7, 8 \& 9. The stills of scenes from Black Mirror antology that contains post-geographical and post-historical elements. From the left to the right: San Junipero (Owen Harris, 2016), USS Callister

Research Article - This article was checked by iThenticate

Copyright (C) The Turkish Online Journal of Design, Art and Communication 
(Toby Haynes, 2017) and Crocodile (John Hillcoat, 2017). Obtained from netflix.com. Accessed on 06.08.20.

Black Mirror anthology stands out with its presentation of a selection of narratives that do this with possible-future fiction, as well as being a production that holds a critical mirror to the present. In this context, postgeographical and posthistorical elements are frequently seen in the series. With the future descriptions shaped by advanced technology in the anthology, the transformation in the way the characters perceive and experience time and space is exhibited. This is achieved through digital technologies, and it is striking that characters inevitably experience this third nature, whether they want to exist in cyberspace or not. Virtual identities, online realities, and blurring of the distinction between the past and future can be listed as prominent themes in the series.

\section{METHODOLOGY}

\section{Interactive Narratives}

The fact that the film is interactive with the audience and has more than one end shows a postmodern interplay of form and content. Bandersnatch, a significant part of the Black Mirror anthology in which Charlie Brooker made social criticism, was examined in the light of concepts such as irony, metanarrative, discipline and surveillance society, technology and individual interaction, loss of individuality and fragmented self, which are the cultural elements of postmodernity.
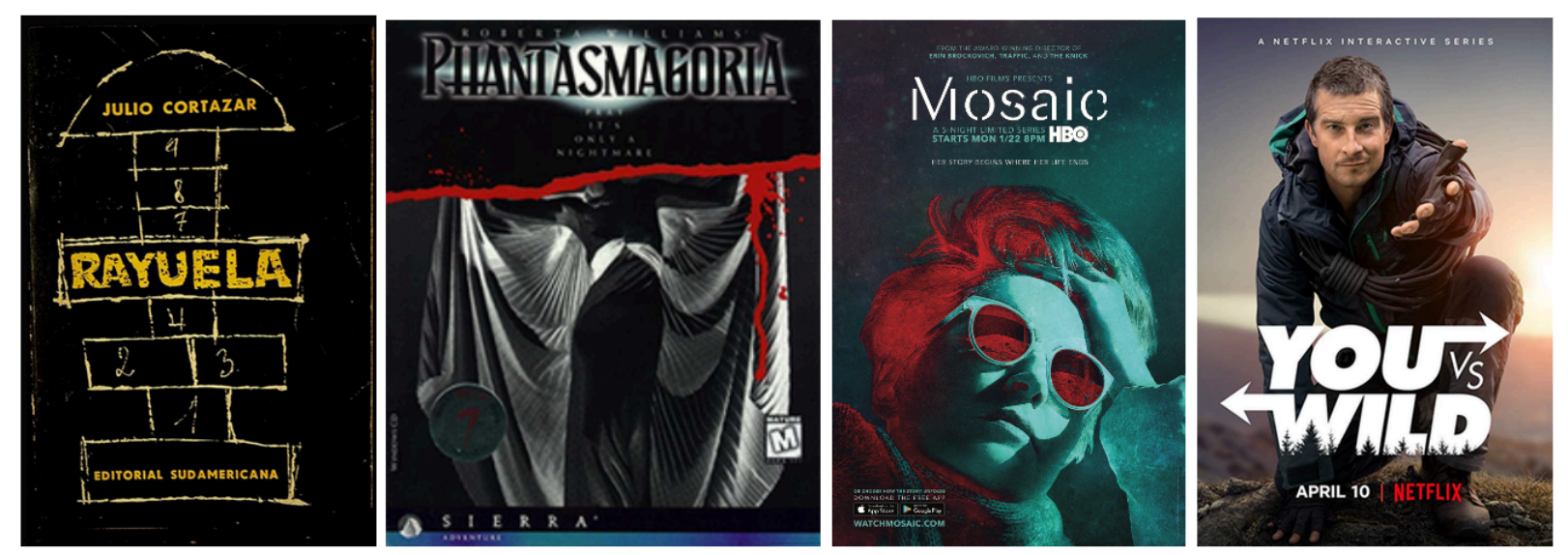

Picture 10,11, $12 \& 13$. The interactive examples of the literature, video games, TV shows and documentaries. Left to right: Hopscotch-Rayuela (1963) Phantasmagoria (1995), Mosaic (2018) and You vs. Wild (2019). Obtained from wikipedia.com. Accessed on 31.01.20.

We can see the first examples of interactive storytelling in the literature. Julio Cortazar's Hopscotch (Rayuela) novel (1963) or Milorad Pavic's Dictionary of the Khazars (1984) narrative allows the reader to make selections and jump back and forth in the story (Kutay, 2019). In the ' 80 s and '90s, world-wide bestseller "Choose Your Own Adventure" series that has this style, was popular between children and young people in Turkey with the release name "Macera Tüneli" (The Tunnel of Adventure). The most popular example of interactive narratives are video games such as Phantasmagoria (1995) or Detroit: Become Human (2018). Steven Soderbergh's Mosaic (2018) for HBO was one of the important examples of TV. Netflix's first interactive experiment was in 2017 with a children animation called Puss in Book: Trapped in an Epic Tale (Roy Burdine \& Johnny Castuciano). Bear Grylls: You vs. Wild (2019) is the most recent example of an interactive documentary. Bandersnatch is the first adult interactive film on a digital platform. In this example, where the postmodern form is integrated with postmodern content, it can be seen that by analyzing certain themes as today's people reflect their concerns about self, society, and technology.

\section{General Information on Analysed Film}

Research Article - This article was checked by iThenticate

Copyright (C) The Turkish Online Journal of Design, Art and Communication 


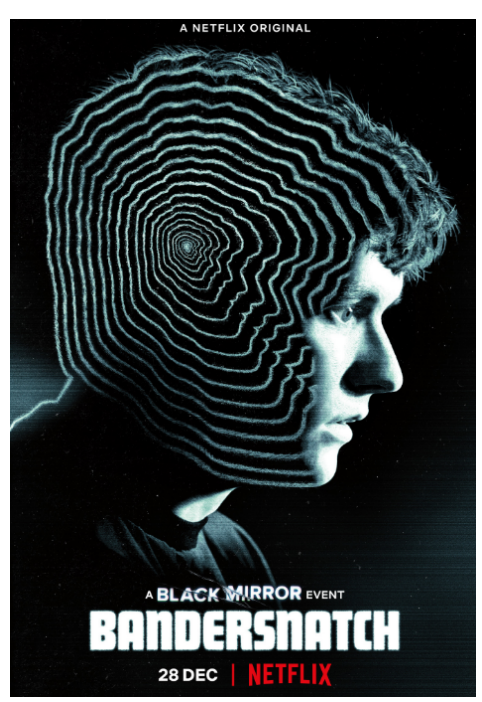

Picture 14. Official Poster. Obtained from imdb.com. Accessed on 26.03.19.

\author{
Release Name: Black Mirror: Bandersnatch \\ Director: David Slade \\ Writer: Charlie Brooker \\ Main Cast: Fionn Whitehead, Craig Parkinson, Alice \\ Lowe, Will Poulter \\ Directors of Photography: Aaron Morton, Jake Polonsky \\ Producers: Charlie Brooker, Annabel Jones \\ Companies: House of Tomorrow, Netflix \\ Countries: USA, UK \\ Worldwide Release Date: 28 December 2018 \\ Runtime: 90-150 min.
}

Logline: In the interactive film, audience make decisions instead of a young programmer Stefan Butler (Fionn Whitehead), who struggles to adapt a "choose your own adventure" style novel into a video game in 84 's London.

\section{Interpretative Repertoires}

Interpretative repertoires are used repeatedly in a certain style and grammar structure in evaluating and qualifying actions, events and many other facts; often organized around unique metaphors and ways of speaking; culturally familiar and conventional argument index, gathered around recognizable themes, clichés and metaphors, is described as a bundle of routine definitions and evaluations. It is accepted as the executive building blocks of discursive action as the meaning structures known and shared by others that people use to build versions of an important event and express social life. Interpretation repertoires are explanatory frameworks that are built in a historical, social and cultural context, are continuous and relatively resistant to change. These discourse tools are expressive patterns that are readily available in daily interactions and establish various communications as subjective actions. In a sense, it is based on quotes from different interpretation repertoires that people or listeners are familiar with, even if they are originals that they speak or write (Potter \& Wetherell, 1987; Wetherell \& Potter, 1988, 1992; Edley, 2001; Reynolds \& Wetherell, 2003 as cited in Paker \& Akşit, 2012, p.561).

We estimate that; popular culture images such as films can be analysed by interpretative repertoirs because certain kinds of images can be produce in the complexity of a certain discourse as Gillian Rose discusses in her book Visual Metodologies, when she mentiones a study on art history which uses a "visual interpretative repertoire" (Rose, 2001, p.157) Rose cites Jonathan Potter that interpretative repertoires are something like "mini discourses" tend to be quite specific to particular social situations. These mini discourses develop historically and make up an important part of the 'common sense' of a culture, although some are specific to institutional domains (Potter, 1996 as cited in Rose, 2001, p.156).

In this study, discourse of Bandersnatch film will be analysed though three basic interpretative repertoires
a. "Loss of individuality"
b. "Loss of reality"
c. "Decentralization"

These repertoires will be evaluated with companion themes such as paranoia, cyberspace, digital simulation, surveillance and free will which are the mini discourse elements derived from Black Mirror anthology. Discourse analysis is used in this study which is handled with the qualitative method. 


\section{FINDINGS}

The plot of the film is briefly as follows:

In 1984, England, young programmer Stefan Butler (Fionn Whitehead), the author of "Bandersnatch" Jerome F. Davies (Jeff Minter) -who reminiscent of the science fiction writer Philip K. Dick- wants to adapt "choose your own adventure" book, to a video game. Game is on; without being caught to the creature named "Pax", passing through a graphical maze via selecting the screen instructions. Butler begins programming the game for the video game company Tuckersoft, executed by Mohan Thakur (Asim Chaudhry), and also including the famous game creator Colin Ritman (Will Poulter). Stefan Butler blames himself for the death of his mother at a young age. While on therapy at Doctor Haynes (Alice Lowe), he lives with his father, Peter (Craig Parkinson), whom he doesn't quite get on with or trust. For weeks, Butler locks himself at home for trying to prepare the game, but gradually he loses control.
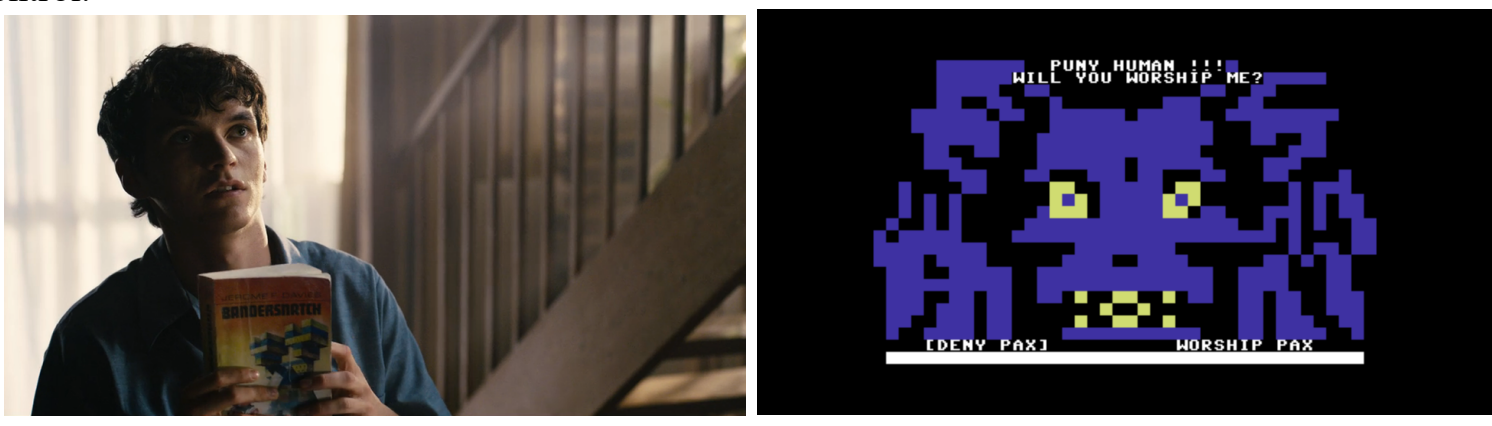

Picture $15 \&$ 16. Stills from Bandersnatch. On the left: the protagonist Stefan Butler with the Bandersnatch book, on the right: the interface of the Bandersnatch game which the protagonist developed. Obtained from netflix.com. Accessed on 31.01.20.

The film was inspired by Imagine Software, a company that plans to release a video game with the same name in real life in the same year, but fails. Bandersnatch is also the name of a fictional character, who came to life in Through the Looking-Glass (1871) and The Hunting of the Snark (1874) of Lewis Carroll, author of Alice's Adventures in Wonderland (1865).

On Netflix platform (2019), the film presented as, "in 1984, a young programmer began to question reality while adapting a dark novel to a computer game. A story that pushes the boundaries of the mind and has multiple ends". As in the totalitarian regime of Big Brother described in the 1984 novel (George Orwell, 1948), surveillance also prevails in Bandersnatch. Surveillance is offered by the Netflix platform to the audience as an option. The audience has the right to surveillance and control, by controlling the film's main character Stefan Butler, as Big Brother did in 1984.

\section{Interpretative Repertoire 1: "Loss of individuality"}

The structure of the film is dominated by repetition. Stefan wakes up every morning at the same time, and follows the same routine. The film draws the audience into a loop, depicting the effect of control and surveillance on the individual. Besides, Stefan is shown to have lived under the control of "program and control" (the abbreviation is PAC) in the film without having his own choices. This is a reference to the famous computer game "Pac-Man". Pac-Man, is constantly escaping from his enemies in a simple labyrinth. There is no exit from the labyrinth, and when you move from one direction off the screen, you enter the labyrinth again from the opposite direction. At this point, the film shows the similarities of each individual with Stefan who lives in a capitalist society. While we think that we make our own choices, and continue our lives with our free will, we, like all humanity, live on the axis of choices that do not belong to us, with the laws of our own surveillance. In this context, like all Black Mirror anthologies, the Bandersnatch film provides a critical view of today's world, and maintains a mirror the way people live. 


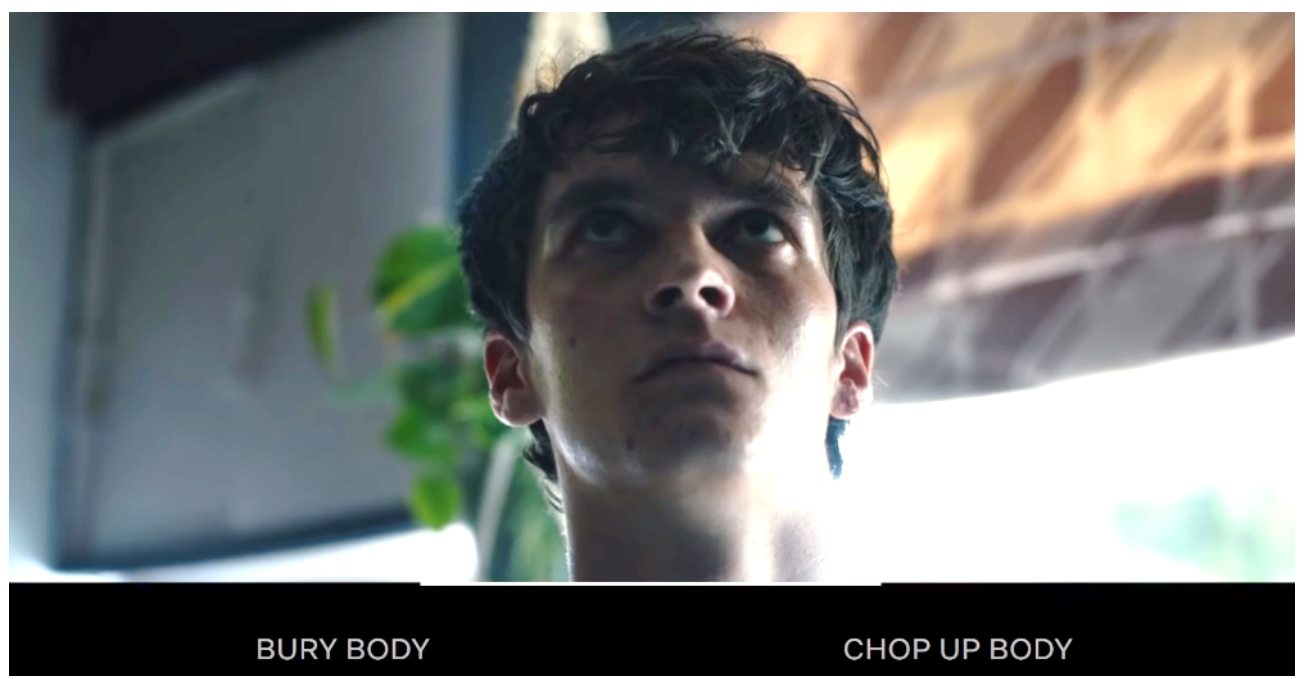

Picture 17. The choice between bad and worse. Obtained from netflix.com. Accessed on 26.03.19.

However, the active audience role starts to break as the film progresses. As Stefan begins to lose control, the audience stops identifying with Stefan, and becomes one of the elements controlling Stefan in the film's narrative. Sometimes the choice alternatives are single-handed or forced to choose between bad and worse, such as "bury the father" and "break apart the father" indicates that the feeling of "free will" in the hands of the audience is an illusion. All of the unhappy endings of the film return to a sense of identification when Stefan and the audience see that they have the same illusion of free will.

Stefan having psychological problems, but at the same time as a fictional character of the reality that to the fact he is controlled by the audience approach interrupted that the authority figure is by the psychotherapist and father characters. From the perspective of Michel Foucault, such a real quest for authority and society is sufficient to be considered insane, and the individual must be controlled in this sense by various social institutions. Similarly, the brand of cereal selected for breakfast appears later on TV as a commercial. The first choosing scene of the film, on the other hand, is reminiscent by Truman's wife in Truman Show (Peter Weir, 1998) who advertise any brand constantly, she and Truman's entire life is under observation and watched live by the public. Again, as Foucauldian sense, platforms like Google, Facebook and Netflix have algorithms that save our choices and then use them as advertisements. Digital systems that transform information into knowledge and spread knowledge through networks and establish dominance over the individual are described in the film via control mechanisms.

\section{Interpretative Repertoire 2: "Loss of Reality"}

Although the film passes in the $80 \mathrm{~s}$, it looks at the present day from the $80 \mathrm{~s}$ and describes today as a dystopia. When Stefan rebels and asks "who controls me?" one of the options to answer is Netflix itself. Bandersnatch's postmodern irony and self-referencing arise within the narrative. When Stefan tells this to his therapist, the therapist says, "Then why aren't you in a more entertaining scenario?" and continues: "You're talking to an ordinary woman in an ordinary room in an ordinary world". 


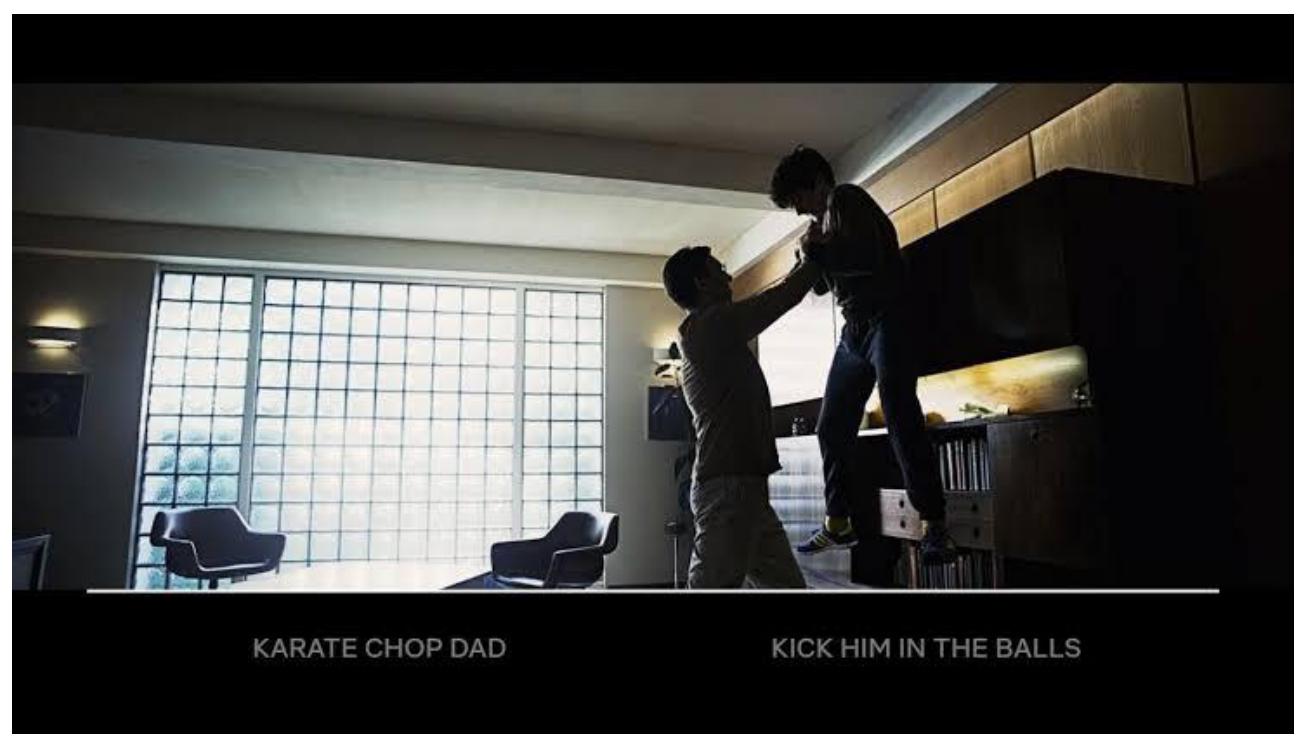

Picture 18. Loss of reality by the sudden change in narrative. Obtained from netflix.com. Accessed on 07.08.20.

In fact, Netflix's general attitude on stories is based on action, comedy, or crime-based stories, and Bandersnatch has a static structure. After the therapist's question, another choice appears, but this is not really a choice. Both "yes" and "absolutely yes" choices drive the film a meaningless action and an Eastern style fight begins between the therapist and Stefan. This scene can be interpreted as that there is a criticism against Netflix which is sometimes presented meaningless fiction and accused of using sexuality and action only for commercial reasons. This criticism can be read as a criticism of the audience themselves who demands violence and sexuality.

\section{Interpretative Repertoire 3: "Decentralization"}

In the beginning of the Bandersnatch, the film allows the main character to identify with the audience. It is functional for the audience to choose what to eat for breakfast, or what music to listen on the bus, to identify with the audience and feel within the film. In fact, in the context of "monomyth", Stefan's refusal to call to the game company's owner, is the fact that this choice started the adventure, triggers the oldest identification mechanism in storytelling technique. With this, the story gives the audience the impression that they have "free will" to choose. Therefore, an "effective audience" role is adopted in film in terms of interaction with the film's narrative.

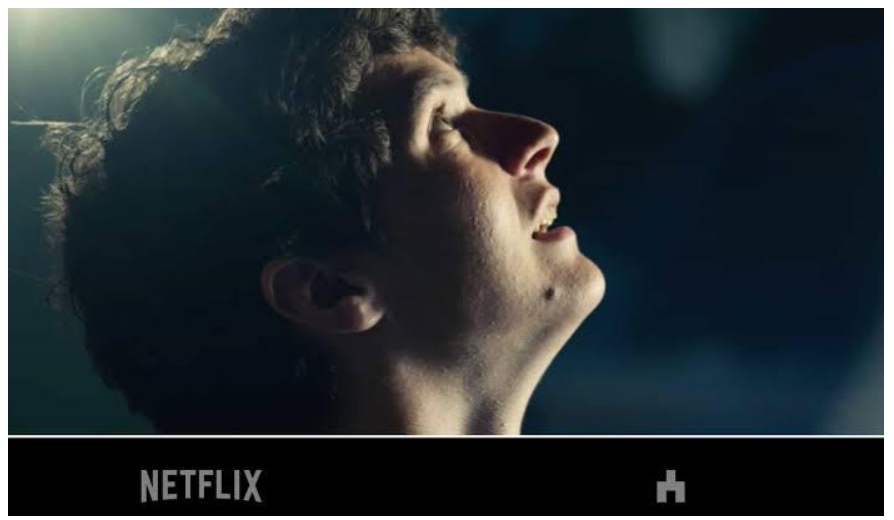

Picture 19. Fragmented reality via decentralization. Obtained from netflix.com. Accessed on 07.08.20.

Bandersnatch novel in the film, written by Jerome F. Davis, described in Stefan's words as "choose your own adventure book". Later, Stefan, who used the phrase "You decide what the character will do," refers 
to the multi-layered structure of the film with the emphasis that the audience also decides for Stefan's actions. So, it can be said that the film is made up of three layers: The fictional Bandersnatch book, written by Jerome F. Davis, the fictional Bandersnatch game, which was programmed by Stefan Butler, and finally the Bandersnatch film, constructed by the audience. Thus, reality-fictional and reality-virtual come together through choices.

\section{DISCUSSION}

This study aims to examine the representation of the relationship between individual and technology in interactive fiction. The Netflix platform is a worldwide popular production and brings content to the audience as a carrier of postmodern narrative forms. In this context, it is seen that the Netflix contains examples that can follow the portrayal of individual in the form of techno-cultural narratives. The relationship between technology and the individual appears with strong imagery and narrative in Black Mirror anthology, especially Bandersnatch film, an experimental work of Black Mirror, which is outstanding in this context. Interactive fiction is a reflection of postmodernity and the examples are known as products in which the reader or audience actively contributes to. From this point of view, Bandersnatch offers an example that is compatible with the technology, both by presenting the narrative through a digital platform and the way the narrative is interactive. The film is a content suitable to analyze as a multi-layered and open-to-interpretation text in terms of presenting the relationship between the individual and technology within the narrative and involving the audience in the dystopian process presented.

The research problems identified in this context are gathered under three main headings, therefore it is aimed to contribute to the analysis with three main themes. These are determined by the purpose to build a background for the repertoires that outline the research. The first of these titles is to question the position of the individual in the social environment. The transformational effects of the individual's existence in society have become evident through technology. Distinctive identifiers of the individual, transform into the Internet through the social networks, so that identity in cyberspace becomes liquid and redefined. The second theme that stands out in the literature review is the possibility of communication technologies to become surveillance tools. Communication technologies can be defined as tools that can contain negative features for the individual, limit the individuality and have the potential to transform the intellectual and behavioral motives of the individual.

Contrary to the features that affirm technology and facilitate the human life of technology, by the second theme negative effects of technology, which are the vehicle and carrier of cultural transformation with the limitation on the individuality, are underlined. The third theme stands out in the literature review, points to the perceptual transformations that people experience. They may experience in the possible future as a result of the meeting of post-geographical and post-historical concepts along cyberspace. Innovations in the field of transportation, inventions within the framework of communication tools and the development of digital technologies, as well as space technologies, open ways to the perceptual and experiential transformations. With the spread of techno-culture, individual's perceptions of time and space have also transformed.

The technological tools that provide the journey of humanities to history have extended the concept of the past to another point by extending the archaeological and paleontological studies. Also, with communication tools, a chance arises to store the memories of people and the visibility and sensibility of the past have been moved to a distinctive position. Besides, the possibility of moving humanities into the future through artificial intelligence becomes a controversial issue. Post-human approaches that paved the way for this give signals that human beings can settle in a post-history and post-geographical position.

To develop the research of the study, the literature on individual and technology has been reviewed and Black Mirror anthology has been interpreted through, and the concepts stand out in the literature and repetitive discursive and imaginary structures in the anthology have been determined. In the analysis

Research Article - This article was checked by iThenticate 
part, a repertoire formulated based on the interactive fictional structure that stands out in the Bandersnatch, the choices of the audience that create the journey of the characters and thus their presentation styles and identities, and images that have cyberpunk influences. In the disposition of this repertoire, the discursive structures that stand out in the Black Mirror anthology are discussed. The resulting repertoire is intended to coincide with the literature analysis. Accordingly, three main repertoires have emerged that form the structure of the research.

The results obtained in the repertoire analysis are interpreted as follows:

- a. "Loss of individuality": According to Jean Baudrillard, we are all "Cypher"s (a character from Matrix, 1999) who consent to a simulated reality that we don't have to touch anything directly or have to deal with the discomfort of resistance (as cited in Shaw, 2008, p.24). With the film, which contains an interactive fiction, presents a retrospective view from a possible post-historical dimension that would come across in the digitalized world and presented a dystopian depiction by carrying the audience to geography that individuals would not even make their own decisions. The fact that our senses, perceptions, and behavioral patterns can be carried to a different dimension in a possible-simulation world is presented to the audience in an alternative universe. And this situation is parallel with the fact that even in today's digital world, cyberspace affects our choices in daily life. In this context, Bandersnatch presented criticism of the loss of individuality over the concept of choice.

- b. "Loss of reality": The film also themes the transformation in which technology affects reality. Characters in the Bandersnatch universe seek their direction in a pool of layers through reality. However, the limits of reality are drawn by the creator of the narrative and directed by the audience. In this context, the character in the narrative does not have a free will, nor their existence depends on the instant but the post-geographical and historical setting. The concern that technology will build reality in the distant future is one of the prominent themes in sciencefiction narratives. Possible transformations in the perception of reality caused by the transfer of the individual's existence to the virtual world have been questioned with the Bandersnatch narrative and the audience that reconstructs it through the mediation of technology. Virilio is skeptical of technological development. According to Paul Virilio, technological development has ideological objectives. For him, modern science has shifted away from its philosophical foundations and has become techno-science. It is also a mass techno-culture. In this way, it is not the subject of the progress of history, but the subject of dizziness created by the acceleration of truth (Virilio, 2003, p. 7-8).

- c. "Decentralization": As Manuel Castells discusses; technology does not determine society. Society cannot draw the direction of the technological change either, because scientific discovery, technological innovation and their social application processes involve many factors including individual creativity and entrepreneurship; so that the final result is based on a complex interaction process. Technology is society because society cannot be understood, illustrated without addressing its technological devices. Technology does not determine society. Technology represents society but society does not determine it. Society, rather uses technological innovations. (Castells, 2008, p.6). Information technologies have been designed through commercial enterprises of all scales in today's capitalist society. At this point, the impact of individualization is vast in postmodern society, thus advantage of postmodernity is polyphony. Netflix is known all over the world for producing content that responds to rising polyphony. It conforms to the definition of decentralization, with the representation of different cultures, languages, social structures, beliefs, orientations, and post-human \& post-geographical narratives. Bandersnatch does not hold onto a center with its narrative structure that moves away from time and space but also emphasizes the decentralized structure with its interactive setup. In Bandersnatch's narrative, decentralization is shaped via existential inquiry, pressure of choice, the desire of the individual to move out of time and space with the technology and escape to reality with gamification.

Submit Date: 06.07.2020, Acceptance Date: 10.08.2020, DOI NO: 10.7456/11004100/013

Research Article - This article was checked by iThenticate

Copyright (C) The Turkish Online Journal of Design, Art and Communication 


\section{CONCLUSION}

The film Black Mirror: Bandersnatch is a dystopia pointing to the present, with a critique of the present that drives the audience to think about free will and choice by giving the message that the individual is under surveillance and control on the axis of technology. With the Bandersnatch film, the audience was asked to make decisions, but those decisions were nevertheless kept within the boundaries of a control mechanism, and the irony that surveillance and control cannot coexist with free will is given as the main message. The Bandersnatch film, which is said to be an interactive production, brought a critical perspective on the concepts of freedom and free will. Bandersnatch film gives a message for the understanding of freedom notion of today's people by showing that free will is limited to the choices given in an established order dominated by social rules, laws and control mechanisms and the film presents dark scenarios for the society based on technology like other Black Mirror productions.

In today's life, the individual draws a profile that allows technological tools to control and allows information and communication technologies therefore surveillance in all areas of his life. The individual transforms themselves into data for brands by shopping with credit cards while sharing their own selves with their social media accounts. An individual who confidently confronts companies, governments, and technological tools, offers the right to control themselves. People are alienated from their nature and produce for consumption by drowning in the same routine in metropolises and moving away from a meaningful life. Although Black Mirror productions present the dystopian structure of the individual drowns in, with a critical eye seem pessimistic in this sense for the messages, although, Black Mirror narratives expect to be understood by the audience by creating hope and to be studied more in the academic world. So let's listen to Nietzsche's call (as cited in de Mul, 2005, p.8): "There is yet another world to discover, and more than one! Embark, philosophers!"

\section{REFERENCES}

Arendt, H. (1994). İnsanlık Durumu (Trans. B. Sina Şener), İstanbul: İletişim.

Batukan, C. (2017). Robo-tizm Robot, Android, Sayborg ve Yapay Zekada Ruh Üzerine, İstanbul: Altıkırkbeş.

Bilgin, N. (2007). Kimlik İnşası, İzmir: Aşina.

Carroll, L. (2000). Köpan Avı (Trans. B. Pirhasan), İstanbul: Roll.

Carroll, L. (2010). Alice Harikalar Diyarında ve Aynanın İçinden (Trans. K. Erzincan Kına), İstanbul: İthaki.

Castells, M. (2008). Enformasyon Çă̆ı: Ekonomi, Toplum ve Kültür (Trans. E. Kılıç), İstanbul: İstanbul Bilgi Üniversitesi.

Castells, M. (2016). İletişim Gücü (Trans. E. K1lıç), İstanbul: İstanbul Bilgi Üniversitesi.

Cortazar, J. (2019). Seksek (Trans. N. Işık), İstanbul: Can

De Mul, J. (2008). Siberuzayda Macera Dolu Bir Yolculuk (Trans. A. Özdamar), İstanbul: Kitap.

Erdoğan, İ. \& Alemdar, K. (1990). İletişim ve Toplum, İstanbul: Bilgi.

Furedi, F. (2001). Korku Kültürü: Risk Almamanın Riskleri (Trans. B. Yıldırım), İstanbul: Ayrıntı.

Hood, B. (2014). Benlik Yanılsaması, (Trans. E. Özdemir), İstanbul: Ayrıntı.

Konsbruck, R. L. (2009). Impacts of Information Technology on Society in the New Century, https://www.zurich.ibm.com/pdf/news/Konsbruck.pdf

Kutay, U. (2019). Yanılsamamayı Seçmek. Birgün. 7 Ocak.

McLuhan, M. \& Povers, B. R. (2001). Global Köy: 21. Yüzyılda Yeryüzü Yaşamında ve Medyada Meydana Gelecek Dönüşümler (Trans. B. Öcal Düzgören), İstanbul: Skala.

Research Article - This article was checked by iThenticate

Copyright (C) The Turkish Online Journal of Design, Art and Communication 
Melucci, A. (2013). Oyuncu Benlik (Trans. B. Kıc1r), İstanbul: Sel.

Orwell, G. (2016). 1984 (Trans. C. Üster). İstanbul: Can.

Paker, O. \& Akşit, O. (2012). Popüler Kültürde Bedenin Dönüşümü ve Tekno-bilimsel Güzelliğin İnşası, International Journal of Social Sciences, Vol. 5(7), p. 553-571.

Pavic, M. (2015). Hazar Sözlüğ̈̈ (Trans. İ. Yerguz), İstanbul: Aylak Adam.

Pickstone, J. (2005). Elusive Memories of Technoscience, Perspectives on Science, Vol.13, no.2, MIT Press.

Shaw, D. B. (2008), Technoculture: The Key Concepts, Oxford: Berg.

Slade, David (Director). (2018). Black Mirror: Bandersnatch [Film]. USA, UK: House of Tomorrow, Netflix.

Virilio, P. (2003). Enformasyon Bombası (Trans. K. Şahin), İstanbul: Metis.

Wells, H. G. (2019). Zaman Makinesi (Trans. V. Gürses), İstanbul: İthaki.

Yazıc1, T. \& Karlı, İ. (2016). Bilgi Toplumunda Teknoloji, Medya ve Siyaset, İstanbul: Volga. 